\title{
The Organizational Paradox in Advertising and the Reconfiguration of Project Cooperation
}

\author{
Caroline von Bernuth \& Harald Bathelt
}

\begin{abstract}
Version Post-print/accepted manuscript
Citation von Bernuth, C., \& Bathelt, H. (2007). The organizational paradox in (published version) advertising and the reconfiguration of project cooperation. Geoforum, 38(3), 545-557.

Copyright / License (C) 2007. This manuscript version is made available under the CC-BYNC-ND 4.0 license.

http://creativecommons.org/licenses/by-nc-nd/4.0/

Publisher's Statement The version of record [von Bernuth, C., \& Bathelt, H. (2007). The organizational paradox in advertising and the reconfiguration of project cooperation. Geoforum, 38(3), 545-557.] is available online at:

http://www.sciencedirect.com/science/article/pii/S0016718506001576 [doi:10.1016/j.geoforum.2006.10.009]
\end{abstract}

How to cite TSpace items

Always cite the published version, so the author(s) will receive recognition through services that track citation counts, e.g. Scopus. If you need to cite the page number of the TSpace version (original manuscript or accepted manuscript) because you cannot access the published version, then cite the TSpace version in addition to the published version using the permanent URI (handle) found on the record page. 
September 9, 2006 (final revisions)

ca. 11,000 words (incl. ref.)

\title{
The Organizational Paradox in Advertising and the Reconfiguration of Project Cooperation
}

\author{
Caroline von Bernuth \\ University of Marburg, Faculty of Geography, \\ Deutschhausstraße 10, 35032 Marburg, Germany, \\ E-mail: cvonbernuth@gmx.net \\ and \\ Harald Bathelt* \\ University of Toronto, Department of Political Science, \\ Sidney Smith Hall, 100 St. George Street, Toronto Ontario, Canada M5S 3G3, \\ E-mail: harald.bathelt@utoronto.ca, \\ URL: http://www.harald-bathelt.com
}

Paper to be submitted to

Geoforum

* Corresponding author 


\title{
The Organizational Paradox in Advertising and the Reconfiguration of Project Cooperation
}

\begin{abstract}
In recent literature, projects are mostly seen as an efficient form of organization which is particularly suited for mastering tasks of high complexity and creativity and adapting to changing economic and institutional conditions. This paper challenges the assumption that inter-firm projects are persistent organizational arrangements of production in the advertising industry and presents a novel argument about the potential threats to forms of project organization in crisis situations. By exploring the cases of Frankfurt/Main and Leipzig (East Germany), we show that the organization of production is substantially affected by periods of economic crisis or political transformation. We demonstrate that inter-firm projects might be replaced by more durable organizational configurations or might not be viewed as viable options in situations of severe rupture. This applies particularly to the cooperative arrangements in the creative process and leads to an organizational paradox. Although creativity is often a pivotal force to gain competitive advantage, the advertising agencies respond to the challenges of crises by reducing cooperation with external partners to a minimum and sometimes fully rely on in-house personnel. This threatens the potential of the respective firms to develop innovative and creative ideas which would enable the firms to acquire new customers and market segments. Instead of trying to overcome crises by focusing on their creative capabilities, many advertising agencies develop a cost-cutting strategy and rely on more durable network-forms of organization instead of inter-firm projects.
\end{abstract}

Keywords: inter-firm projects, advertising industry, organizational paradox, creativity, crisis, Leipzig, Frankfurt/Main 


\section{Introduction}

In the past years, there has been an increasing academic interest in projects as an organizational form of economic processes. This is due to the increasing importance of projects in large parts of the economy. Some observers might even interpret this as a tendency of projects to replace other forms of economic organization, such as firms and networks, as has been observed in the Hollywood motion-picture industry (e.g. Storper and Christopherson 1987). Since projects are organized at an inter-personal level and often cross firm boundaries, they seemingly question the firm as starting point of the analysis of the economic process (DeFillippi and Arthur 1998). Projects are a thoroughly structured, temporary organizational form based on the principle of short-term cooperation. Important characteristics are their institutionalized ending and strong goal orientation (Lundin and Söderholm 1995). In contrast, other organizational forms, such as networks, emphasize the importance of ongoing, trustbased linkages between firms. Projects are mostly regarded as an efficient form of organization which is particularly suited for mastering tasks of high complexity, stimulating creativity and individual learning and adapting to changing economic and institutional conditions.

Focussing on inter-firm projects, this paper challenges the assumption that projects are a persistent organizational configuration of production, drawing on the case of the advertising industry. The advertising industry was chosen because it is characterized by an almost idealtype structure where inter-firm project organization is the rule rather than the exception. By exploring the cases of Frankfurt/Main and Leipzig, it will be shown that the organization of production is substantially affected by periods of economic crisis or political transformation (Bathelt and Jentsch 2004). To a certain degree, we support the view that projects are a flexible organizational arrangement capable of adjusting themselves to many challenges in the 
market environment. In this respect, projects can be more efficient than other, more durable organizational arrangements. In this article, we intend to provide evidence that projects might be replaced by more permanent forms of economic organization in periods of economic or political crises, which is, in part, due to some limitations.

The shift in the organizational form applies particularly to the cooperative arrangements in the creative process and leads to an organizational paradox. Tapping into different mindsets and knowledge pools generally opens up opportunities for creativity. This can be a great help in coming up with new, 'trendy' ideas and designs which enable people to leave the normal path of routine solutions. As such, creativity is an important feature to access new markets and compete for contracts. Although creativity is often a pivotal force to gain competitive advantage, the advertising agencies studied respond to the challenges of crises by reducing cooperation with external partners to a minimum and sometimes fully rely on in-house personnel. This threatens the potential of the respective firms to develop innovative and creative ideas which would enable them to acquire new customers and market segments. Based on empirical evidence from the Frankfurt/Main and Leipzig advertising industries, it will be shown that many agencies develop a cost-cutting strategy and rely on more durable network-forms of organization during a crisis, instead of trying to overcome this crisis by focusing on their creative capabilities in inter-firm projects.

In discussing this organizational paradox, our paper aims to contribute to recent discussions in relational economic geography by exploring how firms, in regional perspective, respond to crisis situations by changing their organizational structure which, in turn, affects the development path of the respective regions (e.g. Bathelt and Glückler 2003). The paper is organized as follows. In section 2, the merits and challenges of project organization are discussed. At first, a review is given of the advantages and characteristics of project organization. Then, we point out three types of challenges and problems which exist in projects compared to more durable organizational forms. These challenges are related to the 
establishment of (i) cumulative organizational learning, (ii) trust and (iii) power relations which are conducive to 'efficient' project work. It is argued that project organization is particularly likely to occur in contexts which are characterized by a clear-cut inter-personal division of competencies and a high need for creative solutions. Section 3 presents the cases of Frankfurt/Main and Leipzig to demonstrate that inter-firm advertising projects tend to shift towards more durable network arrangements in periods of crisis. In the case of Leipzig, characteristics of the advertising industry and its project structures are discussed, which have developed during the course of the political transformation after the Reunification. In contrast to Leipzig, Frankfurt has a large, well-developed advertising sector of national importance. Here, the structure of cooperation in projects is affected by economic stagnation and substantial cutbacks in advertising expenditures.

\section{Merits and Challenges of Project Organization}

Depending upon the perspective chosen, nearly every economic activity could be viewed as a project. Practically all workflows in firms are based on temporary goals and access to resources. Once these goals are achieved, occasional decisions are made about the future distribution of these and further resources. This is even the case in the context of industrial mass production. A good example for this is the automobile industry. Since such forms of organization can even be traced back to medieval times, it would not be true to say, however, that projects are a new way of organizing capitalist labor processes. Based on Giddens' (1990) analysis of the development of modern society, we would argue that the increasing importance of projects and their sophisticated division of labor are a consequence of the dynamics of modernity, stimulated by systematic reflexivity in processes of knowledge creation. A trend towards 'projectification' (Midler 1995) would fulfill the associated needs for structured production as it involves reflexive learning processes build around a sequence 
of milestone meetings and flexible team structures that can be adjusted to the particular problem to be solved.

In general, three types of projects can be distinguished, i.e. (i) inter-firm projects, (ii) intra-firm projects, and (iii) projects as independent temporary firms or organizations (Ekinsmyth 2002). Using a broad definition of projects which encompasses all of these types, however, it would be difficult to examine the specific character of projects. In this paper, we focus on inter-firm projects since this type of organization has received relatively little attention in the past. Inter-firm projects cross the boundaries of firms to fulfill a particular economic goal within a given time period. We view projects as an organizational arrangement or form which differs from other organizational forms, such as hierarchies, markets and networks (Figure 1). Differences between these organizational forms are due to aspects, such as durability and institutionalized ending, the degree of interdependence between agents involved, the type of power relations, the degree of reciprocity and character of social interaction, as well as the type of coupling between the project partners (e.g. Bathelt and Glückler 2003). Our treatment of projects is thus related to the discussion regarding which governance mechanisms occur in economic transactions, depending on the type and context of the transactions (e.g. Williamson 1985; Granovetter 1985; Grabher 1993). In the next section, some of the important characteristics and advantages of inter-firm project work will be highlighted and compared with other organizational arrangements. The specific challenges and problems which confront project work will then be analyzed.

\subsection{Merits of Project Organization}

Projects are often regarded as an ideal organizational form as they are capable of dealing with the rising complexity of products and services, rapid changes in markets and increasing uncertainties (Hobday 2000). In this context, projects are seen to be different from more durable organizational forms, such as permanent networks, firms and clusters (Engwall 
1998). It is widely acknowledged that project-based cooperation has a number of advantages compared to other organizational configurations. For instance, costs and risks can be minimized (DeFillippi and Arthur 1998; Ekinsmyth 2002). Inter-firm project work is also conducive to the development of new creative solutions and access to a wider customer basis (Grabher 2001), beyond that which could be achieved within the dominant routines and narrow mindsets of a single firm.

In contrast to firms, networks or clusters, projects have a given time horizon and predefined deadlines. They are a typical organizational form in areas such as film production, advertising, music recording, the building of motorways, etc. A project usually begins when a goal has been set and the contract signed and ends when the specific project task is achieved (Lundin and Söderholm 1995). Goals and tasks bind the participants of a project together as a team (Grabher 2002a). In contrast, cooperation in firms and networks is based on durable systems of goals and often entails a permanent commitment of the people involved (Maskell and Lorenzen 2004). Similar to networks, projects are characterized by an extended interpersonal and inter-firm division of labor and are based on interdependent relations between the project participants.

In most industries, projects rarely exist in isolation from other organizational forms. In the advertising industry for instance, they are typically organized across firm boundaries and involve a mix of different people from within the main agency, as well as freelancers and people from other firms. This illustrates that projects do not easily question or replace other, more durable organizational forms. Rather, they are often inseparably intertwined with these firms and networks and build upon their existence (Grabher 2004a; 2004b; Ibert 2004). In addition, projects are embedded in personal relationships and specific localities (Grabher 2002b). There is a whole stream of literature that stresses the importance of embeddedness in classical, more permanent organizational forms, such as firms and networks. They act as resources for inter-firm projects from which team members can readily be selected, according 
to the particular goals to be fulfilled (e.g. Coe 2000; Starkey et al. 2000; Ekinsmyth 2002; Grabher 2002b; Sydow and Staber 2002). Of course, projects not only benefit from their organizational and institutional context but, in turn, also structure an industry context in a reflexive manner (Windeler and Sydow 2001).

Since many people with different qualifications from various departments of a firm, as well as from other firms, work together in a project, a project manager is needed to coordinate and supervise the team members and their activities. The project manager is the reference person for all participants and has the task of establishing trust relations between the participants. This is not an easy task, since projects, just like firms, are characterized by an asymmetrical distribution of information and power. The project manager specifies work standards, job orders, the social division of labor and is responsible for the distribution of incomes and profits. He/she also links the project team to the customer, who defines the deadlines for the project, sets the pace of the work to be conducted and, in many cases, is the decision-maker. The decisions made by the customer and those made jointly with the project manager regarding the standards and tasks serve to structure the project into successive stages and provide some certainty for the participants. Through this, each team member can relate his/her own work to the final goal (Grabher 2002a).

In contrast to firms and networks, projects are not as dependent on the specific infrastructure provided in particular places as in more permanent settings, such as a firm's workplace (DeFillippi and Arthur 1998). Project members do not have to own this infrastructure if there are possibilities to rent it from others. In this respect, projects strongly benefit from being embedded in fully-fledged clusters where such services are generally available. Their spatial structure is thus more flexible ${ }^{1}$ because they can take place in different

\footnotetext{
${ }^{1}$ However, they might stick to major clusters where a wide range of services is available (e.g. Hollywood
} in the case of film production in the USA). 
contexts and represent temporary places for knowledge exchange and generation (Amin and Cohendet 2004). Sometimes, the participants always meet at one particular place, where they interact throughout the course of the project. In other cases, the project participants are spatially separated from each other when they do their work but meet regularly in personal meetings and/or over virtual interfaces in order to exchange intermediate results.

In the context of a project, we cannot expect that a linear transformation of knowledge takes places where implicit knowledge is simply transformed into explicit knowledge (Bengtsson and Söderholm 2002). Rather, similar to the knowledge-generation process described by Nonaka et al. (2000), different knowledge pools are made mutually accessible to the participants through articulation and discussion. Then they are combined and recombined, whereby knowledge is explicated and internalized in a reflexive manner, until a possible problem solution or project result becomes visible (Johnson, Lorenz and Lundvall 2002). Alternatively, a project can be dissolved before a final solution is reached.

During a project, the participants become familiar with the conceptions and visions of their partners and integrate these into their own practices and contributions. In the long-run, more durable linkages or networks can develop which go beyond the firms' boundaries. Hence, project organization, in itself, contains a mechanism that stimulates more stable social relations. In some industries, it is more difficult to achieve such stable structures between the members of a project team than in others. An example is the film industry, where the participants of a project already start looking for a new job prior to the end of the project and before more detailed information about the commercial success of the last project is available. The chances for follow-up projects with the same participants are very limited (DeFillippi and Arthur 1998).

Possibilities to quickly set up a new project team for a specific task largely depend on existing inter-personal networks and access to a latent pool of specialists. In this process of 
selecting partners for a project team, reputation and 'know-who' play an important role (Gann and Salter 2000; Christopherson 2002; Grabher 2002a).

Clusters are an important basis for projects because they offer various planned and unplanned possibilities for information exchange and learning. Due to similar experiences, firms in dynamic clusters develop a similar understanding and joint institutional basis. The 'local buzz' of information flows which occurs in a cluster supports the development of suitable project teams and enables firms to evaluate new trends (Bathelt 2005). Furthermore, it encourages the exchange of experiences and the formation of what we might call communities of practice (Grabher 2002c; Bathelt et al. 2004). Communities play an important role for individual learning processes in projects because they create a high-trust environment and a common interpretative framework for the participants (Brown and Duguid 1991). This provides an important basis for a multitude of learning processes, such as 'learning by doing', 'learning by watching' and 'learning by interacting' (DeFillippi and Arthur 1998).

Compared to an integrated firm, projects are associated with lower costs, especially if production involves the use of a highly specific infrastructure. Frequent changes in the composition of project teams also generate a degree of high flexibility (e.g. Windeler and Sydow 2001). Through this, it is possible to satisfy different customer needs and provide customer-specific project solutions. At the same time, the changing composition of the teams promotes creativity and prevents lock-in effects. In the advertising industry this is particularly important in the creative phase when a new advertising campaign is developed. In permanent organizational forms, it would, in contrast, be rather unlikely that experimental recombinations of ideas and deviations from established standards and routines take place. To maintain these advantages and be able to cooperate openly, however, a minimum of security, reliability and trust must be developed within a project team. Effective institutions need to be created which reward creative thinking and team spirit and eliminate free riders. 


\subsection{Challenges and Problems of Project Organization}

The previous analysis has shown that inter-firm, inter-personal projects are an efficient form for the organization of economic processes. Following Nonaka et al. (2000), projects could also be regarded as 'ba' or temporary organizational contexts which enable interpersonal learning processes and knowledge transfers. At the same time, they raise problems which concern the sustainability of learning and the generation of knowledge, despite various possibilities for learning processes. Thereby projects might not always be an appropriate organizational form due to the challenges and problems which might exist. There are three types of challenges and problems which are particular to inter-firm projects compared to more durable organizational forms. These are related to the establishment of (i) cumulative organizational learning, (ii) trust and (iii) power relations.

\section{Barriers to organizational learning}

Due to the temporary character and changing composition of participants in projects, the question arises as to how routines can be developed which enable knowledge exchanges and learning processes beyond the duration of an individual project (Hobday 2000). In recent literature, more attention has been paid to the question of how learning processes and knowledge are handled in project-based environments (e.g. Davies and Brady 2000; Gann and Salter 2000; DeFillippi and Arthur 1998; 2001; Keegan and Turner 2001; Husman 2002; Bresnen et al. 2003; Koskinen et al. 2003; Grabher 2004a). Knowledge which is generated during a project is, in the first place, individual knowledge, bound to the team members of the project. To enable cumulative learning and prevent repetition in the learning process in subsequent projects, it is necessary to transfer new knowledge to the organizations from which the project members originate. This is a tricky process, however, which can be 
problematic because people often retain some knowledge for themselves, instead of sharing it with their colleagues.

Therefore, the experiences which team members have collected in prior projects are often crucial for the success of a project (DeFillippi and Arthur 1998). Firms which operate in project-based environments are confronted with the problem of finding external knowledge and resources in a form suitable for new projects (Husman 2002). Different industries use various strategies in handling knowledge and learning processes (Grabher 2004a). One could expect, for instance, that subsequent projects in creative industries are more flexible in terms of the composition of team members than those in technical areas. In contrast, the participants in technical projects are more likely to be stable over the course of several such projects. Overall, knowledge about competitors and the capabilities and trustworthiness of project partners are crucial factors in the success of project-based work.

\section{Problems of building trust}

Another problem associated with projects, is the question of how to generate trust and avoid opportunistic behavior. From recent work, we know that the establishment of mutual trust is greatly supported if potential project partners live in the same agglomeration or cluster, since spatial proximity generates many opportunities for face-to-face contact. Such contact becomes even more important when a project is under time pressure and when the division of labor between project members is not quite clear (Grabher 2002a). For newcomers, spatial proximity to experienced people provides good conditions for the acquisition of knowledge about important conventions and routines through observation and participation. This is a necessary precondition to become an 'insider' (DeFillippi and Arthur 1998; Bathelt and Jentsch 2002).

On the one hand, the creative, technical and financial tasks of project organization require intensive, trustworthy communication between the project participants. On the other 
hand, however, conventional trust, which is based on cumulative learning processes (Lorenz 1999), cannot be easily established due to the temporary character and changing composition of participants from project to project (Koskinen et al. 2003). This is also complicated by the fact that project members are sometimes bound to different loyalties (Grabher 2002a).

Thus, a major challenge of projects is related to the establishment of sufficient trust in order to enable the project members to communicate openly with one another. They have to trust that others will not steal specific knowledge or potentially undermine their competencies. To avoid that free riders harm the atmosphere for knowledge generation, the selection of project participants becomes crucial. This is often based on reputation (e.g. Faulkner and Anderson 1987; DeFillippi and Arthur 1998; Glückler and Armbrüster 2003) and the existence of swift trust (Meyerson et al. 1996), i.e. a form of trust that results from the evaluation of formal qualifications of the potential project partner. Although these mechanisms cannot fully compensate for a lack of conventional trust, they often become the basis for cooperation. As a consequence, it appears that projects are especially likely to develop in contexts which are characterized by a clear-cut social division of labor. If only a small overlap of individual competencies exists, unintended knowledge transfers are less likely to occur.

\section{Projects and power relations}

A further challenge of project cooperation is related to the workings of power relations. These are intrinsically unequal in character (Taylor 1995; Allen 1997). Due to the changing composition of participants, power relations have less time to develop and stabilize in projects as opposed to more durable organizations. As in other organizational forms, power asymmetries nevertheless create some sort of hierarchy and dominance within a project. This is supported through project-specific power mechanisms, such as deadlines and milestones which serve as governance mechanisms and are driven by the dominant roles of the project 
leader and the client. The resulting power asymmetries can be beneficial but may also create problems. On the one hand, they may help settle conflicts between participants and speed up decision-making processes. If conversations are too conflict-ridden and project partners insist on different advertising strategies, the prospects for a successful culmination of the project, on the other hand, may be in danger and the chances for path-breaking solutions be reduced. The question is therefore how to establish stable power relations within the course of a project in such a manner as to enable efficient translation and transfers of knowledge between the project partners despite the temporal limitation of projects. This is a similar question to that which caused Latour (1986) to rethink the meaning of power. He redefined power as a force that is not simply owned or possessed by someone but rather results from social practices, for instance, in the way how third parties can be enrolled into joint action.

Due to the constantly changing composition of the participants in a project and the selection of team members with different experience, taste and attitude, a collision of different 'cultures' may occur. Although a heterogeneous mix of people might be beneficial in that it increases the potential for unique creative solutions, large cognitive differences in the sense of diverging knowledge bases might limit the potential for successful interaction (Nooteboom 2000). This may cause project instability.

Another problem may be related to the distance which exists between the project partners (Allen 2003). Communication might suffer as people operate in different organizational contexts and regions with their own peculiarities. Individuals and firms may, for instance, be used to different practices in conducting business with each other, which partners to involve and which not, which 'language' or metaphors to use when communicating, how to combine written statements and gestures in exchanging preliminary project results and the like. In short, this is associated with the existence of implicit knowledge which is not easy to transfer over distance (Maskell and Malmberg 1999). 
In the literature, it is often somewhat nebulous as to how power relations in projects are organized and how cooperation can be assured. In practice, however, implicit knowledge about how project members envision cooperation appears to play an important role. This implicit knowledge, which affects the ability of project partners to interpret the actions and reactions of others, appears to greatly affect the way in which projects are structured and how they are coordinated. This knowledge results from experience in previous projects and allows for an efficient circulation of knowledge, as long as the other team members share these implicit images. An open question which remains is which mechanisms a contractor can implement to support the establishment of supportive power relations in setting up a project team.

In sum, projects can be characterized as a form of organization which is particularly well-suited to solve production tasks which require a high degree of creativity, willingness to experiment and flexibility. This applies in particular to creative industries, such as design and advertising. If, however, economies of scale gain in importance and similar or larger contracts are made, projects are likely to shift into more permanent forms of economic organization, such as firms or networks. In this case, of course, the previously discussed problems associated with establishing trust and supporting cumulative learning processes disappear over time.

Similar developments can be expected in periods of crisis or political change. We argue in the remainder of the paper that, in some contexts, inter-firm projects are not necessarily the organizational outcome of production even if they were at the outset. Particularly, in severe crisis situations agents might focus on other, more permanent arrangements such as firms and networks instead of projects. Over time, inter-firm projects might not be a persistent phenomenon in economic transactions in the case of severe economic or political crises. We suggest that this is, in part, due to some of the challenges and problems which are associated 
with project organization, as well as the existing loyalties in performing strategies to secure incomes.

In contrast to firms, project work is usually not characterized by strong technological or organizational routines which have developed in a cumulative way. A lack of routines, in turn, likely makes the team members' interaction and their reactions to crisis situations less predictable. The project manager has the task of making adjustments to accommodate changes in the external conditions. To accomplish this, he/she has to mediate between the different people and organizational 'cultures' involved in the project (see, also, Andersen 2003). This can easily produce conflicts and lead to situations where firms prefer other organizational forms. This will be investigated further in the following sections, drawing on the cases of the Frankfurt/Main and Leipzig advertising industries.

\section{Changes in Project Organization in the Advertising Industry}

The advertising industry has always been characterized by a project-based labor organization. This has a number of advantages for the firms involved. There is a constant input of fresh ideas in the creative process and the variety of customer requests can be fulfilled by simply changing the participants in a project and hiring the appropriate specialists. Advertising projects can be organized at relatively short notice and are usually focused around agencies which implement project structures according to customer wishes. Typical areas for such work are the production of TV spots or the development of product brands, organized around a 'budget'. Despite the long-term perspective offered by such budgets, production is split up in successive projects. These are completed separately but are bound together by a larger advertising strategy (Grabher 2001).

Typically, inter-firm advertising projects not only involve suppliers and service providers with complementary skills but also include freelancers. Creative tasks may be 
undertaken by other firms, freelancers or may be done in-house because agencies have their own departments which do creative work. As such, these projects cross the boundaries of firms in both vertical and horizontal directions. Since jobs in advertising are typically customer-specific, close communication and coordination between the producers and their customers are decisive (Grabher 2002b). Especially the first stages of a project require close interaction between the customer's marketing people and the contractor's account manager, as well as between the account manager, account planner (who is responsible for the development of an advertising strategy and links the creatives with information about market trends and consumer needs) and the pool of creatives. Through this, the team members are able to come up with an advertising concept which satisfies the customer's needs and builds upon the agency's strengths.

Major projects in the advertising industry are always a challenge because it is necessary to organize a creative process which is partly unforeseeable. This process needs to be organized under great time pressure and various specialists coordinated under the umbrella of the project (Husman 2002). As opposed to film production, the project teams in advertising do not completely change from project to project, especially as longer-term producer-customer relations and partnerships develop on the basis of successful projects. This general structure of advertising projects can be identified in both cities. The respective industries in Frankfurt/Main and Leipzig have nonetheless each developed their own particular characteristics, which differ from those in other leading centers of advertising, such as London (Grabher 2001).

In the following sections, we analyze how advertising projects in Frankfurt/Main and Leipzig have been affected by economic crisis and political transformation. In particular, the strategies agencies have applied to cope with these situations of crisis will be discussed. We aim to provide empirical evidence that inter-firm projects are not necessarily the organizational outcome of production even if they were quite pervasive at some point, a 
phenomenon which has not yet received much attention in the literature. Severe crisis situations can lead to a situation where agents tend to focus on other, more permanent arrangements, such as firms and networks (as in the case of Frankfurt) or where they do not even develop an elaborate project organization (as sometimes in the case of Leipzig).

\subsection{Methodology}

The analysis presented is based on two separate case studies of the Leipzig media sector and the Frankfurt/Main advertising industry, parts of which have been published elsewhere (e.g. Jentsch 2004; Bathelt 2005). As will be shown, the advertising industries in both cities have different characteristics and the type of crisis experienced also differs substantially. While Frankfurt/Main has experienced an acute economic crisis, Leipzig (East Germany) suffers from chronic problems as a consequence of the political transformation related to the German Reunification. Therefore, it would be difficult to compare both case studies with one another. Our main goal is, however, not to compare the two empirical cases. Despite the different contexts, Frankfurt/Main and Leipzig were chosen because they show that severe economic and political crises can lead to situations where projects are being replaced by other, more durable forms of economic organization or where they are no viable organizational option to choose from.

Due to differences in the development of both cases and the availability of data, the selection of firms was based on different data sets. In Frankfurt/Main, we were able to access a well-structured data bank of the local industry association which lists advertising agencies according to the statistical definition of this industry (Industrie- und Handelskammer Frankfurt/Main 2002). In contrast, we were only able to use a firm directory which was based on a self-classification of firms in the case of Leipzig (Stadt Leipzig 2000). In order to emphasize this difference, the terms 'advertising firms' and 'advertising agencies' are used to refer to members of the advertising industry in Leipzig and Frankfurt/Main, respectively. This 
does not affect the analysis presented as it is not our goal to compare both cases with one another.

The subsequent analysis is largely based on interviews with account managers and owners of advertising agencies, as well as additional interviews with planners, industry specialists and the like. The Leipzig case is based on 22 interviews with firms in the areas of advertisement/ PR/ marketing and graphics/ design which were conducted in July 2000 and March and April 2001. In Frankfurt/Main, a total of 20 interviews were conducted between November 2002 and March 2003. Both large international advertising groups and small owner-led firms were selected for our interviews (Table 1; Table 2).

\subsection{Economic Crisis and Change in the Frankfurt/Main Advertising Industry}

With a turnover of more than 2.6 billion Euro in 2000, Frankfurt/Main is one of the most important centers in the German advertising economy (Arsenschek 2002). Although Frankfurt/Main is usually not known as being as creative as Hamburg, it also hosts some wellknown important agencies. The city's success in this industry was initiated by location decisions of large advertising groups (network agencies) from the USA which established their German or European base in Frankfurt/Main in the post-World War II period. This especially occurred in the 1960s and 1970s, as a consequence of the presence of numerous American manufacturing firms in the region (Slesina 1987; Kellner 1995). ${ }^{2}$

Except for these international advertising groups, the agency landscape in Frankfurt/Main is primarily characterized by many small, owner-led agencies which have been founded later on, especially during the 1990s. This was also reflected in our sample (Table 3). The growth of Frankfurt/Main into a center of the advertising industry is related to

\footnotetext{
${ }^{2}$ Further, the growth of the advertising industry was also stimulated by the role of Frankfurt/Main as
} Germany's major financial center. 
the high density of consumer good producers (or important facilities of these firms) with major advertising budgets (Horizont 2002), as well as its strategic location in Germany and access to a large international airport.

According to data of the chamber of commerce (Industrie- und Handelskammer Frankfurt/Main 2002), Frankfurt/Main hosted 315 advertising agencies in 2002, most of which are concentrated in central locations such as Westend and the areas around Zeil and Hanauer Landstraße (Figure 2). Along with these agencies, the city has developed a broad infrastructure of suppliers and service firms to the advertising industry. This is important as agencies rely on spatial proximity to potential suppliers, creatives and other service providers to complete complex projects which require close monitoring of all participants under rigid time pressure (Jentsch 2004).

In the city, projects of different magnitude and complexity are accomplished with the involvement of numerous external project partners on both local and international levels. Interestingly, we found that the relationship between agencies and customers was not as intensive as in other advertising centers, such as London (Grabher 2001) or in Japan (Moeran 2003). Although customers are typically integrated in decision-making processes regarding the selection of specialized or prestigious service providers, e.g. the stage director for a project, they often do not know whether and to which degree their contractors involve external creatives in the conception phase. As opposed to London, the selection of cooperation partners in Frankfurt/Main is strongly based on trust which has been nurtured in previous projects. In both centers, the composition of project teams is also influenced by reputation and builds upon latent networks (Grabher 2001; Jentsch 2004).

Trust between agencies and their project partners becomes more important the higher the costs and time constraints of a project. Small agencies, which often do not have departments responsible for such areas as account planning or art buying, are more dependent on external partners than large agencies. Further, firms which operate fairly self-sufficient 
without contacts with larger advertising groups, often rely primarily on local project partners. In contrast to advertising groups, they tend to choose the same partners in subsequent projects, creating a network rather than a project structure. Larger advertising groups and agencies with former employees from such groups draw from a larger pool of potential project partners than small firms. They benefit from processes of agency hopping through which they establish contacts with many other firms at an inter-personal level.

The tendency of advertising agencies in Frankfurt/Main to rely on partners from previous projects is not only a matter of trust. Rather, repeated cooperation with the same partners has a self-reproductive effect due to specific competencies which result from joint interaction. Agencies become quite familiar with the standards and procedures of their partners which allows for efficient communication. This also helps to mobilize individual knowledge which has been obtained at a personal level in earlier projects. Due to this practice to rely on known partners, some agencies have developed a close network of service providers and freelancers with whom they cooperate. In contrast, agencies in the London advertising industry are seemingly much more interested in constantly involving new partners who are engaged in other projects to get access to a broad competence and knowledge pool which guarantees a high degree of novelty (Grabher 2002b; Grabher 2004a). Overall, the linkages between project participants in Frankfurt/Main appear more stable than those in the dynamic London advertising scene.

Even small agencies in Frankfurt/Main mentioned that they do not rely on the assistance of local institutions when looking for suitable external partners. Based on their experience, they have access to a pool of potential project partners or rely on the recommendations of colleagues in these firms. In putting together new project teams, these firms usually do not see a need to contact the growing number of independent production managers and art buyers who operate as freelancers in the region and have access to a large number of potential project partners. Particularly around large agencies, structures develop or exist which can be 
interpreted as communities of practice (Jentsch 2004). The former employees of these agencies stay in close contact with each other and with their previous employers. They share information about the characteristics and capabilities of potential project partners and participate in the local and non-local buzz. Their common work background enables them to transmit new information efficiently and interpret it in a useful way. In crisis situations, these inter-personal networks generate a competitive advantage for the agencies involved because they have immediate access to important new information.

Since 2001, the German advertising industry has experienced a severe economic crisis. Stagnation tendencies in the German economy have prompted many firms to reduce advertising expenditures (Riering 2002). According to data of the Association of the German Advertising Industry (Zentralverband der deutschen Werbewirtschaft 2002; 2003), customers reduced their annual advertising expenditures by $5.0 \%$ in 2001 and by another $5.9 \%$ in 2002 . For the advertising agencies interviewed in Frankfurt/Main, this crisis in advertising expenditures has become apparent through increased price pressure from the customers and an increase in competition. Advertising groups, for instance, which have traditionally focused on large budgets, have since begun to compete for smaller projects with small owner-led agencies. Another consequence of the crisis is that customers avoid making longer-term contracts with individual agencies. This leads to an intensification of the hierarchical power relations between customers and agencies in a dualistic way.

Most agencies have reacted to this economic crisis by making cutbacks in employment. Our study clearly shows that agencies have also reduced the extent of cooperation with external creatives and other suppliers to reduce costs. ${ }^{3}$ Further, agencies in Frankfurt/Main pass on the increasing price pressure which originates from the customers to their service

\footnotetext{
${ }^{3}$ Interestingly, advertising agencies in Los Angeles also rely strongly on internal resources and are not
} engaged in broad inter-firm relations (Pope 2005). 
providers and freelancers. They are forced to sell their services at dumping prices to get any business at all. As a consequence of these cutbacks, almost all agencies interviewed cooperate less with external partners than before the crisis (Bathelt and Jentsch 2004). This has resulted in an organizational paradox in the creative process. Instead of trying to use external partners to come up with innovative or creative advertising campaigns which could provide them with additional contracts in the future, cost-cutting measures have received priority. Through this, agencies reduce interaction with external partners, especially creatives, to a minimum and rely on intra-firm resources. ${ }^{4}$ In most agencies, external creatives are only contacted if the internal capacities are fully employed. They have not recognized the capacity of external creatives to help overcome the crisis (Jentsch 2004). ${ }^{5}$

At the same time, the number of bankruptcies has increased in the supplier and service sector. The fact that the agencies cut down on inter-firm cooperation also appears problematic, as it bears the risk of lock-in. Changes in the supplier sector due to new start-ups might, however, also help agencies abandon old routines once the crisis is over, as this enhances the potential to establish different linkages with new partners.

${ }^{4}$ One could ask why agencies do not externalize their creative tasks to cut costs. This does normally not happen occur because a particular form of creativity is often closely connected to the core competence of an agency. To give up this competence could seriously threaten an agency's image and eventually its performance.

${ }^{5}$ Especially larger agencies also have internal organizational means to encourage creativity, for example by reassigning creative staff or hiring new people. The inclusion of external creatives, however, offers a wider range of option for experiments than would be possible within the set of established routines of a single firm and could help access new markets. Despite the importance of creativity, we also have to keep in mind that not all advertising projects are equally dependent on a high degree of creativity or 'newness'. In general, however, creatvity is a decisive factor in the advertising industry in order to acquire new customers. 


\subsection{Leipzig's Advertising Industry After the Reunification: The Effects of Political}

\section{Transformation}

In contrast to the situation in Frankfurt/Main, the East German advertising industry did not benefit from relocations of prestigious American agencies in the post-World War II period. Instead, the advertising industry in the German Democratic Republic (G.D.R.) remained in the shadow of its West German counterparts. The production of advertising contents was also forced to fulfill particular political goals. The industry experienced only a short growth period during the 1960s, due to an increase in product variety. After 1970, private advertising was almost nonexistent because privately owned firms were transformed into state-led collective companies. Due to this shift, product development in East Germany stagnated. The advertising industry was dominated by the Deutsche Werbe- und Anzeigengesellschaft (DEWAG), a large, vertically-integrated state-owned company which had resulted from nationalization processes (Tippach-Schneider 2004). Creative inputs played only a minor role in the industry because advertising was used as a means of political propaganda and was not influenced by market-led competition.

As a consequence, the Leipzig advertising industry still differs in its structure from that in West German cities and other European advertising centers even 15 years after the Reunification. Differences also exist with respect to the relationship with consumers. There still seem to be differences in the way how people from East and West Germany evaluate advertising campaigns. Their attitudes toward advertising in general, particular topics and even the kind of humor differ (Nöcker 2003). This makes it somewhat difficult for West German firms to enter East German markets.

Although parts of the former DEWAG were based in Leipzig, its advertising industry was in an infant stage at the time of our study. Even today, this industry is still dominated by owner-led advertising firms which primarily focus on print media. They do not require 
creative inputs to the same extent as, for instance, firms which design TV spots. Nearly all of the firms interviewed were founded after the Reunification (Table 4) and had only a few employees (Table 2). According to a local directory of the media industry, the city hosted approximately 107 advertising firms and other firms with partial activities in advertising in 2000 (Stadt Leipzig 2000). Most of these firms were located in or close to the center of Leipzig (Figure 3). According to the sales tax statistics, the annual turnover of the industry amounted to 80.0 million Euro in 2001. Thus, despite the importance of this industry within the new 'Länder', Leipzig is only a secondary center of advertising compared to West German cities. There are only a few potentially interesting industrial customers in the local economy which could attract large international agencies. As opposed to Frankfurt/Main, the local infrastructure of suppliers and service providers is also weakly developed. The absence of large advertising groups limits the prospects of local agency hopping. As has been shown in the case of Frankfurt/Main, agency hopping would be an important prerequisite for the development of latent networks which can support flexibility in projects.

Despite the infant stage of this industry, there are project structures in Leipzig which are similar to those in advertising centers like London or Frankfurt/Main (Grabher 2001; Jentsch 2004). However, there are also numerous differences. Like in Frankfurt/Main, most Leipzig firms view themselves as full-service agencies. From their point of view, they have the competencies required to do most of their business in-house. Advertising firms in Leipzig are only rarely involved in an extensive social division of labor with external specialists or complementary partners. Most firms interviewed have little contact with other specialized agencies and do not cooperate with others (Bathelt 2005). They are only interested in partnerships with other firms, if customers want to expand their business into a new field which is not covered by the agency (e.g. web design). According to our interviews, however, such practices are rather an exception. Existing subcontracts involve relatively little interaction, thus limiting the potential for the generation of creative ideas. This low interest of 
individuals in close inter-personal and inter-firm interaction can, of course, only partially be viewed as a consequence of the political transformation process, as successful cooperation has not been the rule beforehand. Our observations suggest that inter-firm project organization has sometimes not been an option for owner-led firms due to negative experiences with both the system of state monitoring in the G.D.R. and the Reunification. A couple of the owners interviewed mentioned in this context that they were still somewhat reluctant to cooperate with other firms because they experienced that a former partner had worked for the 'Stasi', the G.D.R. secret police. According to a study of Metze and Schroeckh (1998), distrust was still an important factor during the mid 1990's. It prevented loose linkages between firms becoming more intensive, involving close interaction between employees at different levels. The 'culture of distrust' (Thomas 2001) which developed since the Reunification, or still exists from the previous time period, seems to prevent firms from engaging in cooperative arrangements. As some interviewees mentioned, firms from West Germany who had moved to Leipzig in the early transformation period did not treat their East German partners in a fair way. In short, the lack of intense local linkages in the Leipzig advertising industry does not serve to stimulate the quality of local buzz. Further, Leipzig's advertising industry is primarily characterized by relatively simple, small projects which often do not require much interaction.

The tendency to avoid close contact with others is also apparent in the communication with customers, creating a structure which has been referred to as the 'distanced neighbor' paradox (Bathelt 2005). Some owners seemed to be anxious to reduce customer contact to a minimum in order to save time and money. They only engage in more intensive interaction in the initial phases of making contact. Even though they aim to conduct regular business with these people, they do not view them as a vital source of ideas to be further exploited. One interviewee mentioned that customer contact that is too close distracts him from the really important tasks. This form of customer contact may be possible in some standardized projects 
but is not sufficient to fulfill more complex tasks. It is, thus, not surprising that only a few advertising firms were found which focus on creative and experimental designs and try to enter new markets. Leipzig's advertising firms tend to concentrate on long-term business relations with regional customers. In the short-run, this seems to offer obvious advantages to the firms. Potential problems can, for instance, easily be solved in personal meetings at short notice. Further, face-to-face contact in ongoing business relations does not need to be as frequent as in new business relations.

At the same time, the advertising firms in Leipzig seem to have problems acquiring customers in West Germany. This reveals an image problem of the East German advertising industry; that is, it is considered to be old-fashioned and not very innovative due to the structures which developed in the G.D.R. West German customers hesitate to do business with advertising firms from the seemingly 'less-creative, under-developed East'. In order to overcome this negative image, one firm from Leipzig initiated a strategic partnership with a Stuttgart-based agency. Most of its creative jobs are now done in Stuttgart. This cooperation was made possible due to the prior existence of close personal relations. Overall, it seems more difficult for East German firms to access West German markets than vice versa.

In addition, the advertising firms are also threatened by competitors from West Germany, which establish small branch offices in Leipzig to gain market access. These agencies, however, execute most of their production and design activities outside the region. Overall, this creates fierce price competition in an already tight local market. As a result, innovativeness and creativity are not decisive factors in competing for contracts with local customers. This serves to freeze conservative structures in the local media industry and blocks off social practices, such as interactive learning or intra-firm project work. It also generates another organizational paradox in the creative process (Bathelt and Jentsch 2004) which is somewhat different from that identified in Frankfurt/Main. Firms focus on price rather than on creativity and innovative design which would be a requirement to access West German 
markets. Therefore, firms continue to rely on the stagnating local market and miss out on developments which take place elsewhere, as this would require a creative focus. It thus appears that Leipzig's growth potential and prospects to develop into a prestigious center of advertising are clearly limited.

\section{Conclusions}

This paper develops an argument which has not yet received much attention in the literature on inter-firm projects as an organizational form of economic production. We have shown that projects are flexible organizational arrangements which can adjust to changes in external market conditions as team members can be chosen according to their specific talents and the characteristics of the task to be solved. At the same time, this phenomenon could be less pervasive as some observers of the recent discussion on project organization might expect. The previously discussed cases of the Frankfurt/Main and Leipzig advertising industries have shown that inter-firm projects might be replaced by other, more permanent forms of economic organization or they might not come into question as alternative organizational arrangements in cases of severe economic or political crisis. The paper emphasizes, however, that such shifts are by no means homogenous over space and time. From a relational view, responses of individual agents and firms depend on the particular context in which they act and interact and the respective historical development path, part of which is related to regional specificities. This becomes clear in the two regional cases studied.

In Frankfurt/Main, project organization is less flexible than expected, as relatively stable networks have developed over time. Projects are often a consequence of ongoing cooperation between the same agencies and project partners. Due to the present economic crisis in advertising expenditures, inter-firm cooperation has been minimized to employ in- 
house resources. Horizontal cooperation with external creatives, such as specialized freelancers, has especially suffered from this.

Despite the changes in the political and economic context due to the Reunification, advertising projects with intensive inter-firm linkages have not yet developed in Leipzig. In contrast, the new structures in this industry restrain rather than support flexible cooperation in projects. This applies to both cooperation with suppliers and customers, as people in advertising agencies are hesitant to cooperate with external partners. This risk-adverse attitude towards inter-firm interaction is due to a number of reasons. Besides price competition and the reliance on non-creative market segments, it is sometimes related to negative personal experiences during the G.D.R. regime or the Reunification period.

Both examples show that organizational configurations have developed in the advertising industry which are susceptible to economic and political crises. The resulting changes in project organization have given rise to a situation in both cities which we refer to as an organizational paradox. To overcome the crises, agencies have shifted their project organization toward a more stable network type of relation and more intensive use of in-house resources, instead of inter-firm cooperation. Rather than concentrating on creativity and innovation to access new market segments and regions, advertising agencies focus on lowering costs. This could potentially draw them into a vicious circle of downsizing and costcutting measures.

The implications of our analysis for future developments are mixed. In Frankfurt/Main, it can be expected that an economic upswing would once again stimulate cooperation with external project partners. In doing so, the agencies can draw from existing or latent networks of service providers and suppliers. This might even give rise to more flexible forms of organization than those that existed before the crisis. In Leipzig's advertising industry, interfirm cooperation is less likely to develop to any great extent, as long as there are no initiatives to stimulate general economic development in the customer and supplier industries. 


\section{Acknowledgements}

Earlier versions of this paper were presented in 2005 at the annual meeting of the Association of American Geographers in Denver, USA and the Nordic Ph.D. conference in Lund, Sweden. We would like to express our gratitude to three referees as well as Andrew Leyshon, whose insights have tremendously helped us to sharpen some of our arguments. We would also like to thank Claes Alvstam, Bjørn Asheim, Meric Gertler, Deborah Leslie, Anders Malmberg, Jerker Moodysson, Païvi Oinas, Andy Pratt, Norma Rantisi and Peter Wood for supportive comments. Further, we would like to thank Tamara Steinbicker, Constantin von Bernuth and Clare Wiseman for their efforts in shaping and smoothening this paper. The opinions presented are, of course, solely those of the authors who contributed equally to this paper.

\section{References}

Allen, J. (1997): Economies of Power and Space. In: Lee, R. and Wills, J. (Eds.): Geographies of Economies. pp. 59-70. London: Arnold.

Allen, J. (2003): Lost Geographies of Power. Oxford: Blackwell.

Amin, A. and Cohendet, P. (2004): Architectures of Knowledge: Firms, Capabilities, and Communities. Oxford: Oxford University Press.

Andersen, E. S. (2003): Understanding Your Project Organization's Character. Project Management Journal 34: 4-11.

Arsenschek (2002): Im Vergleich zu Hamburg ist Frankfurt ein Gigant. (Compared with Hamburg, Frankfurt is a Giant). Frankfurter Allgemeine Sonntagszeitung, No. 6 (10.02.2002), p. 5 .

Bathelt, H. (2005): Cluster Relations in the Media Industry: Exploring the 'Distanced Neighbour' Paradox in Leipzig. Regional Studies 39:105-127.

Bathelt, H. and Glückler, J. (2003): Wirtschaftsgeographie: Ökonomische Beziehungen in räumlicher Perspektive (Economic Geography: Economic Relations in Spatial Perspective). 2nd Edition. Stuttgart: UTB - Ulmer.

Bathelt, H. and Jentsch, C. (2002): Die Entstehung eines Medienclusters in Leipzig: Neue Netzwerke und alte Strukturen (The Genesis of a New Media Industry Cluster in Leipzig: New Networks and Old Structures). In: Gräf, P. and Rauh, J. (Eds.): Networks and Flows: Telekommunikation zwischen Raumstruktur, Verflechtung und Informationsgesellschaft. pp. 31-74. Hamburg, Münster: Lit. 
Bathelt, H. and Jentsch, C. (2004): Wandel der Projektorganisation am Beispiel der Frankfurter und Leipziger Werbeindustrie (Changes of Project Organization in the Frankfurt and Leipzig Advertising Industry). Petermanns Geographische Mitteilungen 148 (4): 44-51.

Bathelt, H., Malmberg, A. and Maskell, P. (2004): Clusters and Knowledge: Local Buzz, Global Pipelines and the Process of Knowledge Creation. Progress in Human Geography 28: 31-56.

Bengtsson, M. and Söderholm, A. (2002): Bridging Distances: Organizing Boundaryspanning Technology Development Projects. Regional Studies 36: 263-274.

Bresnen, M., Edelman, L., Newell, S., Scarbrough, H. and Swan, J. (2003): Social Practices and the Management of Knowledge in Project Environments. International Journal of Project Management 21:157-166.

Brown, J. S. and Duguid, P. (1991): Organizational Learning and Communities-of-Practice: Toward a Unified View of Working, Learning, and Innovation. Organization Science 2: $40-57$.

Christopherson, S. (2002): Project Work in Context: Regulatory Change and the New Geography of Media. Environment and Planning A 34: 2003-2015.

Coe, N. M. (2000): The View From Out West: Embeddedness, Inter-personal Relations and the Development of an Indigenous Film Industry in Vancouver. Geoforum 31: 391-407.

Davies, A. and Brady, T. (2000): Organisational Capabilities and Learning in Complex Product Systems: Towards Repeatable Solutions. Research Policy 29: 931-953.

DeFillippi, R. J. and Arthur, M. B. (1998): Paradox in Project-based Enterprise: The Case of Film Making. California Management Review 40: 125-139.

DeFillippi, R. J. and Arthur, M. B. (2001): Project-based Learning, Reflective Practices and Learning Outcomes. Management Learning 32: 5-10.

Ekinsmyth, C. (2002): Project Organization, Embeddedness and Risk in Magazine Publishing. Regional Studies 36: 229-243.

Engwall, M. (1998): The Project Concept(s): On the Unit of Analysis in the Study of Project Management. In: Lundin, R. A. and Midler, C. (Eds.): Projects as Arenas for Renewal and Learning Processes. pp. 25-35. Norwell: Kluwer Academic.

Faulkner, R. R. and Anderson, A. B. (1987): Short-Term Projects and Emergent Careers: Evidence from Hollywood. American Journal of Sociology 92: 879-909.

Gann, D. M. and Salter, A. J. (2000): Innovation in Project-based, Service-enhanced Firms: The Construction of Complex Products and Systems. Research Policy 29: 955-972. 
Giddens, A. (1990): The Consequences of Modernity. Polity Press: Oxford.

Glückler, J. and Armbrüster, T. (2003): Bridging Uncertainty in Management Consulting: The Mechanisms of Trust and Networked Reputation. Organization Studies 24: 269-297.

Grabher, G. (1993): Rediscovering the Social in the Economics of Interfirm Relations. In: Grabher, G. (Ed.): The Embedded Firm. On the Socioeconomics of Industrial Networks. pp. 1-31. London, New York: Routledge.

Grabher, G. (2001): Ecologies of Creativity: The Village, the Group, and the Heterarchic Organisation of the British Advertising Industry. Environment and Planning A 33: 351374.

Grabher, G. (2002a): Cool Projects, Boring Institutions: Temporary Collaboration in Social Context. Regional Studies 36: 205-214.

Grabher, G. (2002b): The Project Ecology of Advertising: Tasks, Talents and Teams. Regional Studies 36: 245-262.

Grabher, G. (2002c): Fragile Sector, Robust Practice: Project Ecologies in New Media. Environment and Planning A 34: 1911-1926.

Grabher, G. (2004a): Learning in Projects, Remembering in Networks? - Community, Sociality and Connectivity in Project Ecologies. European Urban and Regional Studies 11: $103-123$.

Grabher, G. (2004b): The Markets are Back! Progress in Human Geography 28: 421-423. Granovetter, M. (1985): Economic Action and Economic Structure: The Problem of Embeddedness. American Journal of Sociology 91: 481-510.

Hobday, M. (2000): The Project-based Organisation: An Ideal Form for Managing Complex Products and Systems. Research Policy 29: 871-893.

Horizont (2002): Werbehochburg im Bankenschatten (Advertising Center in the Shade of the Bank Towers). No. 16 (18.04.2002), pp. 69-71.

Husman, T. B. (2002): The Existence, Boundaries and Internal Organisation of Project Organisations. Paper Prepared for the DRUID Winter Conference. Copenhagen (URL: http://www.druid.dk/conferences/winter2002/gallery/brandt.pdf, 23.04.2004).

Ibert, O. (2004): Projects and Firms as Discordant Complements: Organisational Learning in the Munich Software Ecology. Research Policy 33: 1529-1546.

Industrie- und Handelskammer Frankfurt/Main (2002): Location and Size of Firms in the Frankfurt/Main Advertising Industry. Project-specific Analysis. Frankfurt/Main: Industrie- und Handelskammer Frankfurt/Main.

Jentsch, C. (2004): Projektorganisation in der Frankfurter Werbeindustrie (Project 
Organization in the Frankfurt Advertising Industy). Marburg: Fachbereich Geographie, Universität Marburg. SPACES 2004-03 (URL: http://www.unimarburg.de/geographie/spaces, 23.04.2004).

Johnson, B., Lorenz, E. and Lundvall, B.-A. (2002): Why all This Fuss About Codified and Tacit Knowledge? Industrial and Corporate Change 11: 245-262.

Keegan, A. and Turner, J. R. (2001): Quantity Versus Quality in Project-based Learning Practices. Management Learning 32: 77-98.

Kellner, J. (1995): 1945 bis 1995: 50 Jahre Entwicklung der Werbeagenturen in Deutschland (1945 - 1995: 50 Years in the Development of Advertising Agencies in Germany). In: Kellner, J., Kurth, U. and Lippert, W. (Eds.): 1945 bis 1995 - 50 Jahre Werbung in Deutschland (1945 - 1995: 50 Years of Advertising in Germany). pp. 11-18. 2nd Edition. Ingelheim: Westermann Kommunikation.

Koskinen, K. U., Pihlanto, P. and Varharanta, H. (2003): Tacit Knowledge Acquisition and Sharing in a Project Work Context. International Journal of Project Management 21: 281-290.

Latour, B. (1986): The Powers of Association. In: Law, J. (Ed.): Power, Action and Belief: A New Sociology of Knowledge? pp. 264-280. London: Routledge \& Kegan Paul.

Lorenz, E. (1999). Trust, Contract and Economic Cooperation. Cambridge Journal of Economics 23: 301-315.

Lundin, R. A. and Söderholm, A. (1995): A Theory of the Temporary Organization. Scandinavian Journal of Management 11: 437-455.

Lundin, R. A. and Midler, C. (1998): Evolution of Projects as Empirical Trend and Theoretical Focus. In: Lundin, R. A. and Midler, C. (Eds.): Projects as Arenas for Renewal and Learning Processes. pp. 1-9. Norwell: Kluwer Academic.

Maskell, P. and Malmberg, A. (1999): Localised Learning and Industrial Competitiveness. Cambridge Journal of Economics 23: 167-185.

Maskell, P. and Lorenzen, M. (2004): The Cluster as Market Organisation. Urban Studies 41: 991-1009.

Metze, R. and Schroeckh, J. (1998): Kooperation in Ostdeutschland nach der Wende - von zufälligen Verbunden und gezielten Netzwerken (Cooperation in East Germany After the Reunification - Unanticipated Coalitions and Intended Networks). In: Metze, R., Mühler, K and Opp, K.-D. (Eds.): Der Transformationsprozess: Analysen und Befunde aus dem Leipziger Institut für Soziologie (The Transformation Process: Studies of the Leipzig Institute of Sociology). pp. 231-252. Leipzig: Leipziger Universitätsverlag. 
Meyerson, D., Weick, K. E. and Kramer, R. M. (1996): Swift Trust and Temporary Groups. In: Kramer, R. M. and Tyler, T. R. (Eds.): Trust in Organizations: Frontiers of Theory and Research. pp. 166-195. Thousand Oaks: Sage.

Midler, C. (1995): 'Projectification' of the Firm: The Renault Case. Scandinavian Journal of Management 11: 363-375.

Moeran, B. (2003): Field, Networks and Frames: Advertising Social Organization in Japan. Global Networks 3: 371-386.

Nöcker, R. (2003): Wer im Osten wirbt, muss den richtigen Ton treffen. (Those Who Advertise in the East Have to Find the Right Tone). Frankfurter Allgemeine Zeitung, No. 88 (14.04.2003), p. 23.

Nonaka, I., Toyama, R. and Nagata, A. (2000): A Firm as a Knowledge-creating Entity: A New Perspective on the Theory of the Firm. Industrial and Corporate Change 9: 1-20.

Nooteboom, B. (2000): Learning and Innovation in Organizations and Economies. Oxford: Oxford University Press.

Pope, N. (2005): Competitive Commercials: A Geographical Analysis of the Advertising Industry in Los Angeles. Paper Presented at the Annual Meeting of the Association of Geographers, 5-9 April, Denver.

Riering, B. (2002): Das Werbejahr 2001 in Deutschland (The Advertising Year 2001 in Germany). In: Schalk, W., Thoma, H. and Strahlendorf, P. (Eds.): Advertising Annual 2002 für den deutschsprachigen Raum (2002 Advertising Annual for the Germanspeaking Area). Volume 39. München: Econ Ullstein List.

Slesina, H. (1987): Die Werbewirtschaft in Frankfurt (The Advertising Economy in Frankfurt). In: Industrie- und Handelskammer Frankfurt am Main and Magistrat der Stadt Frankfurt am Main (Eds.): Wo die Fäden zusammenlaufen - Medien- und Kommunikationszentrum (Where the Threads Meet - Media and Communication Center). pp.10-11. Frankfurt am Main.

Stadt Leipzig (Eds.) (2000): Branchenhandbuch Medien: Region Leipzig 2000 (Firm Directory of the Media Iindustry in Leipzig 2000). Leipzig: Stadt Leipzig.

Starkey, K., Barnatt, C. and Tempest, S. (2000): Beyond Networks and Hierarchies: Latent Organizations in the U.K. Television Industry. Organization Science 11: 299-306.

Storper, M. and Christopherson, S. (1987): Flexible Specialization and Regional Industrial Agglomerations: The Case of the US Motion-Picture Industry. Annals of the Association of American Geographers 77: 260-282.

Sydow, J. and Staber, U. (2002): The Institutional Embeddedness of Project Networks: The 
Case of Content Production in German Television. Regional Studies 36: 215-227.

Taylor, M. (1995): The Business Enterprise, Power and Patterns of Geographical

Industrialisation. In: Conti, S., Malecki, E. J. and Oinas, P. (Eds.): The Industrial

Enterprise and its Environment: Spatial Perspectives. pp. 88-122. Aldershot: Ashgate.

Thomas, M. (2001): Ein Blick zurück und voraus: Ostdeutsche Neue Selbständige aufgeschobenes Scheitern oder Potenziale zur Erneuerung? (Looking Back and Forth: New Self-Employment in East Germany - Postponed Failure or Potential for Renewal?) Mimeo. Frankfurt/Oder (URL: http://www.biss-online.de/htm_beitraege/thomas ein blick zurueck und voraus.htm, 26.08.2004).

Tippach-Schneider, S. (2004): Das große Lexikon der DDR-Werbung - Kampagnen und Werbesprüche, Macher und Produkte, Marken und Warenzeichen (The Encyclopedia of East German Advertising - Campaigns, Slogans, Producers and Products, Brands and Trademarks). 2nd Edition. Berlin: Schwarzkopf \& Schwarzkopf.

Williamson, O. E. (1985): The Economic Institutions of Capitalism. Firms, Markets, Relational Contracting. New York: Free Press.

Windeler, A. and Sydow, J. (2001): Project Networks and Changing Industry Practices Collaborative Content Production in the German Television Industry. Organization Studies 22: 1035-1060.

Zentralverband der deutschen Werbewirtschaft (Eds.) (2002): Werbung in Deutschland 2002 (Advertising in Germany 2002). Bonn: Verlag edition ZAW.

Zentralverband der deutschen Werbewirtschaft (Eds.) (2003): Werbung in Deutschland 2003 (Advertising in Germany 2003). Bonn: Verlag edition ZAW. 
Table 1. Number of Employees of Advertising Agencies Interviewed in Frankfurt/Main 2002/2003 (Source: Survey Results)

\begin{tabular}{c|c}
\hline Numbers of employees & Number of agencies \\
\hline $1-10$ & 9 \\
$11-20$ & 4 \\
$21-40$ & 2 \\
$41-60$ & 1 \\
$61-100$ & - \\
$>100$ & 4 \\
\hline Total & 20 \\
\hline
\end{tabular}

Table 2. Number of Employees of Advertising Firms Interviewed in Leipzig 2000/2001 (Source: Survey Results)

\begin{tabular}{c|c}
\hline Numbers of employees & Number of firms \\
\hline $1-10$ & 18 \\
$11-20$ & 3 \\
$21-40$ & 1 \\
\hline Total & 22 \\
\hline
\end{tabular}


Table 3. Periods of Formation of Advertising Agencies Interviewed in Frankfurt/Main 2002/2003 (Source: Survey results)

\begin{tabular}{c|c}
\hline Period of formation & Number of agencies \\
\hline $1961-1970$ & 4 \\
$1971-1980$ & 2 \\
$1981-1990$ & 1 \\
$1991-2000$ & 11 \\
$2001-2002$ & 2 \\
\hline Total & 20 \\
\hline
\end{tabular}

Table 4. Periods of Formation of Advertising Firms Interviewed in Leipzig 2000/2001 (Source: Survey Results)

\begin{tabular}{c|c}
\hline Period of formation & Number of firms \\
\hline before 1989 & 1 \\
$1989-1994$ & 13 \\
$1995-2000$ & 8 \\
\hline Total & 22 \\
\hline
\end{tabular}


Figure 1. Organizational Forms of Economic Transactions

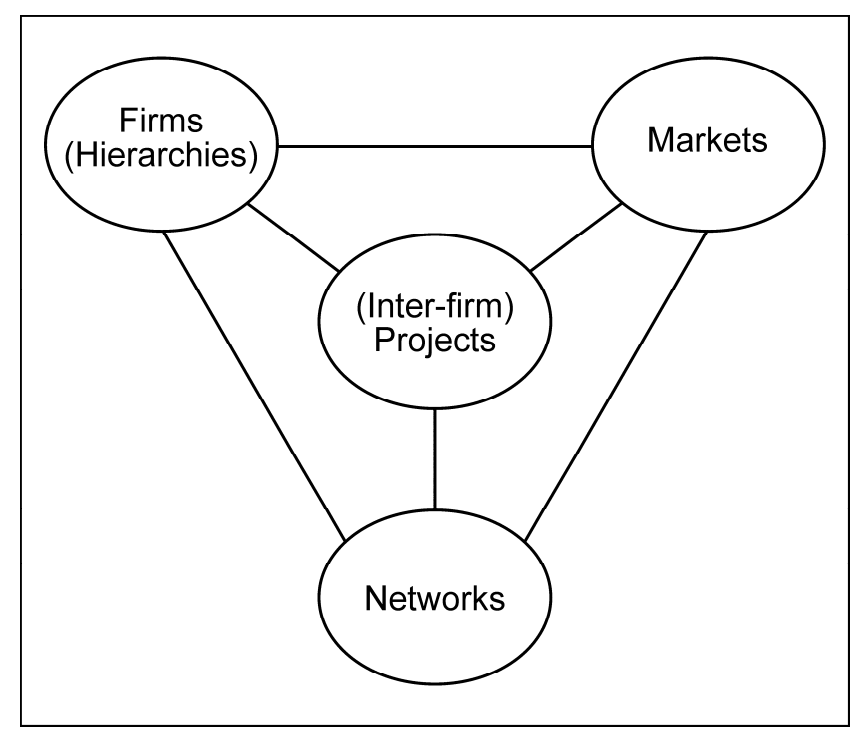


Figure 2. Location of Advertising Agencies in Frankfurt/Main by Postal Districts, 2002 (Source: Industrie- und Handelskammer Frankfurt/Main 2002)

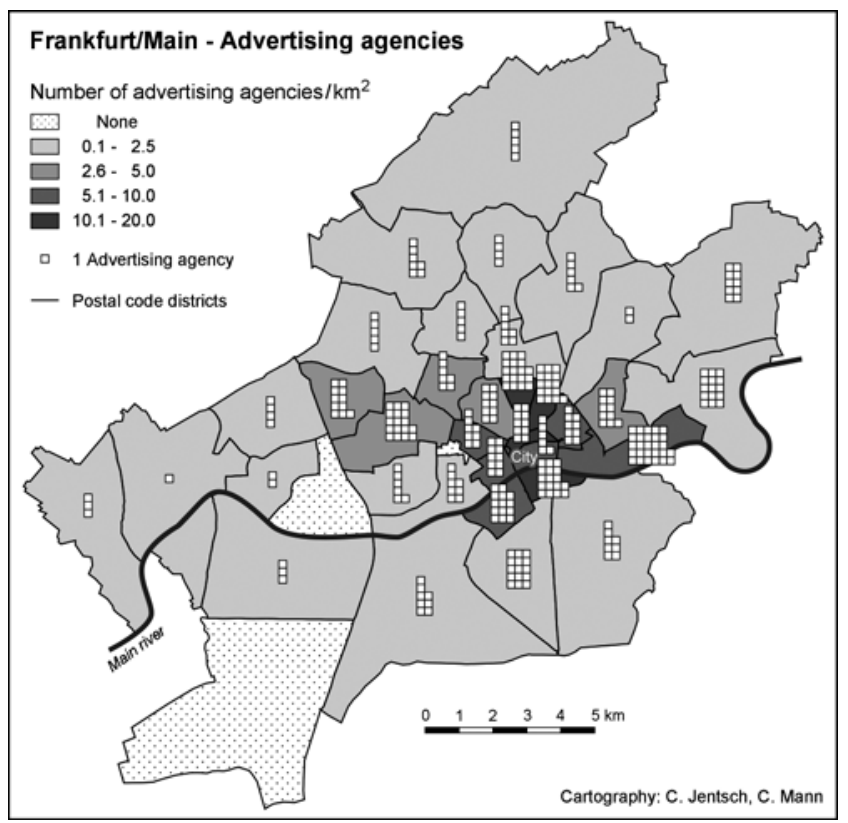


Figure 3. Location of Advertising Firms in Leipzig by City Districts, 2000 (Source: Stadt

\section{Leipzig 2000)}

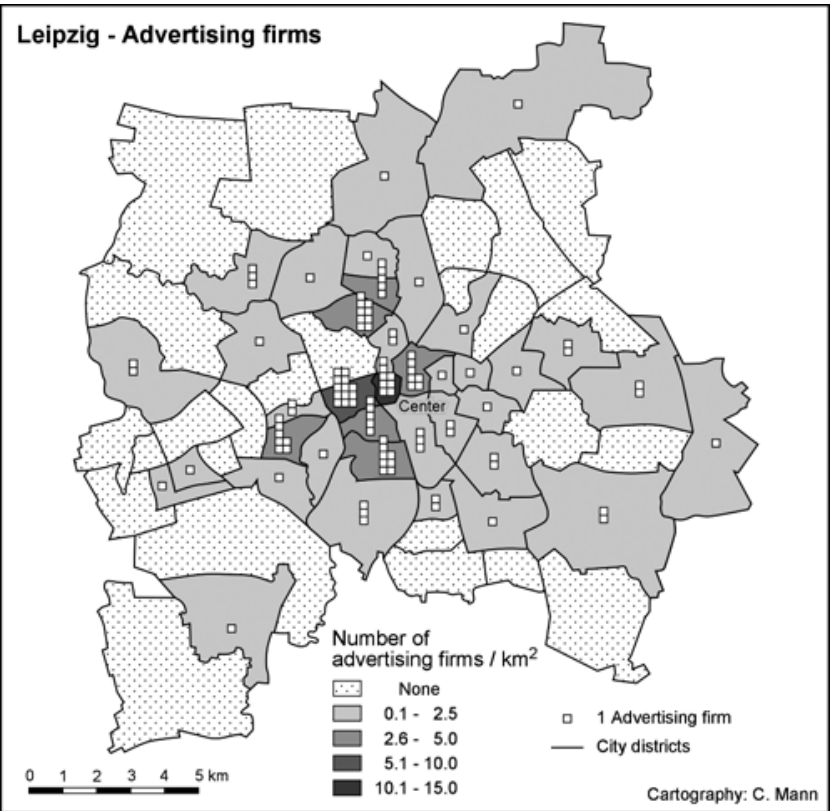

